\title{
THE USE OF SN-10,275 IN THE PROPHYLAXIS AND TREATMENT OF SPOROZOITE-INDUCED VIVAX MALARIA (CHESSON STRAIN) ${ }^{1}$
}

\author{
By THEODORE N. PULLMAN, ${ }^{2}$ LILLIAN EICHELBERGER, ALF S. ALVING, \\ RALPH JONES, JR.,2 BRANCH CRAIGE, JR.,2 AND C. MERRILL WHORTON 2
}

(From the Malarial Research Unit, Department of Medicine, University of Chicago)

(Received for publication December 23, 1946)

A large number of piperidyl quinolinemethanols were investigated for antimalarial activity in avian infections because of close chemical similarity to quinine, as part of the wartime search for new and more effective antimalarial agents. In preliminary observations, $\mathrm{SN}-10,275,3$ or 6,8 -dichloro-2phenyl- $\alpha$-2-piperidyl-4-quinolinemethanol (Figure 1 ), gave greatest indication of promise. It is a compound of the Ainley-King series, which has a high degree of antimalarial activity in cathemerium and lophurae malaria in the duck and moderate activity in gallinaceum and lophurae malaria in the chick (1).

\section{PROCEDURES AND METHODS}

General. Details of the general procedure and the plan of observations are reported elsewhere (2). Healthy

1 This investigation was carried out under contract, recommended by the Committee on Medical Research, between the Office of Scientific Research and Development and the University of Chicago. The studies were planned in cooperation with the Panel on Clinical Testing of Antimalarials of the Board for the Coordination of Malarial Studies. This work was further aided by the participation of Army Medical officers assigned to the project by the Surgeon General, U. S. Army.

Through a cooperative arrangement between Professor Clay G. Huff and Dr. Frederick Coulston, Department of Bacteriology and Parasitology, and the Malarial Research Unit, Department of Medicine, the former group bred Anopheles quadrimaculatus mosquitoes, supervised their infection and the inoculation of volunteers, and determined the intensity of infection in the salivary glands of the mosquitoes. The latter group assumed the responsibility for clinical care of patients studied by both groups.

The authors express their thanks to the Malaria Study Section of the National Institute of Health for editorial assistance and for arrangements in regard to the publication of this paper. They are also grateful to the Abbott Laboratories, E. I. du Pont de Nemours and Company, Inc., E. R. Squibb and Sons, Eli Lilly and Company, Sharp and Dohme, Inc., and Wyeth, Inc., for contributing toward the publication costs.

2 Formerly Captain, M.C., A.U.S.

3 Developed by Buchman and Koepfli and collaborators at the California Institute of Technology.
Caucasian volunteers 4 at Stateville Penitentiary were infected with Southwest Pacific vivax malaria (Chesson strain) (3) by the bites of infected Anopheles quadrimaculatus mosquitoes. This strain is characterized by a high relapse rate when treated with non-curative drugs such as quinine and quinacrine (atabrine), by a short period of latency between successive attacks, and by almost complete absence of delayed primary attacks. In the tests for prophylaxis, three test subjects and three controls were inoculated by bites from the same group of mosquitoes. In the tests for therapeutic activity, five similarly inoculated volunteers undergoing primary attacks or second relapses were treated soon after the appearance of parasitemia.<smiles>OC(c1cc(-c2ccccc2)nc2c(Cl)cc(Cl)cc12)C1CCCCN1</smiles>

Fig. 1. Structural Formula of SN-10,275

Selection of patients. When a series of attacks of (Chesson) malaria, as observed under these standardized conditions, was divided (4) into two groups according to the length of the prepatent and preceding latent periods, there was a significant difference in relapse rate between the groups after treatment with suppressive drugs. The group with short intervals showed a relapse rate of 98 per cent, whereas the group with the longer intervals had a rate of 67 per cent.

In the therapeutic tests, $\mathrm{SN}-10,275$ was administered to two individuals whose attacks belonged to the first group and, therefore, constituted a severe therapeutic

4 The observations reported in this paper would not have been possible except for the enthusiastic cooperation of the inmates and administrative officers at Stateville Penitentiary. 
challenge. It was also tested against three attacks which fell into the group offering a milder challenge.

Drug administration. One gram of SN-10,275 monohydrochloride (equivalent to 0.859 gram of base) per day was administered in four to six divided doses. The subjects in the prophylactic test received drug on the day before, the day of, and for six days after inoculation. The therapeutic trial was conducted at the same daily dosage but consisted of a 14-day course of treatment.

Determination of drug in the plasma. Whole oxalated blood was centrifuged for 15 minutes at 2,000 r.p.m.; the plasma was separated and re-centrifuged for 60 minutes at the same speed to insure complete removal of the components of the buffy coat.

SN-10,275 was analyzed by the method of Butler (5) modified as follows: Five ml. of $0.2 \mathrm{M} \mathrm{Na}{ }_{2} \mathrm{HPO}_{4}$ and 1 $\mathrm{ml}$. of non-fluorescent absolute alcohol were placed in a 50-ml. glass stoppered centrifuge tube. Two or $3 \mathrm{ml}$. of plasma were added to the mixture followed by $15 \mathrm{ml}$. of purified non-fluorescent benzene. The mixture was shaken for 15 minutes, centrifuged and the water layer aspirated. The benzene phase was decanted into $8 \mathrm{ml}$. of 10 per cent $\mathrm{NaOH}$ and shaken for five minutes. After centrifugation and aspiration of the alkali layer, exactly $10 \mathrm{ml}$. of the benzene layer were transferred to a $50-\mathrm{ml}$. glass stoppered centrifuge tube containing $10 \mathrm{ml}$. of $10 \mathrm{~N} \mathrm{H}_{2} \mathrm{SO}_{4}$. After the mixture was shaken for 15 minutes, centrifuged, and the benzene layer aspirated, the acid layer was transferred

TABLE I

Prophylactic effect of $S N-10,275$ on sporozoite-induced $P$. vivax malaria (Chesson strain)

\begin{tabular}{|c|c|c|c|c|c|}
\hline \multirow{2}{*}{ Patient } & \multicolumn{2}{|c|}{ Dose (base) } & \multirow{2}{*}{$\begin{array}{c}\text { Mean } \\
\text { plasma } \\
\text { concen- } \\
\text { tration } \\
\text { during } \\
\text { therapy }\end{array}$} & \multirow{2}{*}{$\begin{array}{l}\text { Prepatent } \\
\text { period } \\
\text { (para- } \\
\text { sitemia) }\end{array}$} & \multirow{2}{*}{$\begin{array}{l}\text { Plasma } \\
\text { concen- } \\
\text { tration } \\
\text { at time of } \\
\text { clinical } \\
\text { attack }\end{array}$} \\
\hline & Daily & Total & & & \\
\hline & grams & grams & $\begin{array}{l}\text { gamma } \\
\text { per liter }\end{array}$ & days & $\begin{array}{l}\text { gamma } \\
\text { per liter }\end{array}$ \\
\hline $\begin{array}{l}1 \\
2 \\
3\end{array}$ & $\begin{array}{l}0.859 \\
0.859 \\
0.859\end{array}$ & $\begin{array}{l}7.0 \\
7.0 \\
7.0\end{array}$ & $\begin{array}{l}680 \\
860 \\
530\end{array}$ & $\begin{array}{l}66 \\
97 \\
74\end{array}$ & $\begin{array}{r}66 \\
81 \\
110\end{array}$ \\
\hline \multicolumn{4}{|c|}{ Three controls } & $12,13,12$ & \\
\hline
\end{tabular}

to cuvettes. The fluorescence was read in a Coleman 12 A photofluorometer with B-1-S and PC-1 filters.

Recoveries and standards were run simultaneously with the unknown.

\section{RESULTS}

Prophylactic effect. The results are summarized in Table I. All three patients developed parasitemia and fever. However, the prepatent periods in the test group were six to nine times as long as those in the control group. The plasma concentrations at approximately the time of appearance of parasitemia ranged from 66 gamma per liter to 110 gamma per liter.

Therapeutic effect. The results are summarized in Table II. The two cases that presented a severe therapeutic challenge relapsed. Of the three cases that offered only a moderate challenge, one relapsed. The others have been followed for over a year. Drug disappeared from their blood plasma 108 and 135 days after end of therapy.

Following treatment with $\mathrm{SN}-10,275$, the latent periods of those individuals who relapsed were 296, 107 and 99 days. The median latent period observed with quinine and quinacrine in the Chesson strain of malaria under the conditions of this investigation, is 15 and 34 days, respectively (6). The plasma concentration of $\mathrm{SN}-10,275$ at approximately the time of appearance of parasitemia ranged from 59 to 80 gamma per liter.

Concentration of $S N-10,275$ in the plasma. $\mathrm{SN}-10,275$ remained in the plasma for long periods after medication had been discontinued. The falling curves of plasma concentration are shown for eight subjects in Figure 2. There was a wide variation in rate of fall from individual to individual. One subject differed markedly from the remainder of the group in that the drug persisted

TABLE II

Therapeutic effect of $S N-10,275$ on vivax malaria (Chesson strain)

\begin{tabular}{|c|c|c|c|c|c|c|c|}
\hline \multirow{2}{*}{ Patient } & \multicolumn{2}{|c|}{ Dose (base) } & \multirow{2}{*}{$\begin{array}{c}\text { Mean plasma } \\
\text { concentration } \\
\text { during } \\
\text { therapy }\end{array}$} & \multirow{2}{*}{$\begin{array}{c}\text { Type of therapeutic } \\
\text { challenge }\end{array}$} & \multirow{2}{*}{$\begin{array}{l}\text { Latent period } \\
\text { (parasitemia) }\end{array}$} & \multirow{2}{*}{$\begin{array}{c}\text { Plasma } \\
\text { concentration } \\
\text { at time } \\
\text { of relapse }\end{array}$} & \multirow{2}{*}{$\begin{array}{c}\text { Length of } \\
\text { observation } \\
\text { since end } \\
\text { of therapy } \\
\text { in negative } \\
\text { cases }\end{array}$} \\
\hline & Daily & Total & & & & & \\
\hline $\begin{array}{l}1 \\
2 \\
3 \\
4 \\
5\end{array}$ & $\begin{array}{l}\text { gr̃ams } \\
0.859 \\
0.859 \\
0.859 \\
0.859 \\
0.859\end{array}$ & $\begin{array}{l}\text { grams } \\
12.0 \\
12.0 \\
12.0 \\
12.0 \\
12.0\end{array}$ & $\begin{array}{c}\text { gamma per liter } \\
1,200 \\
550 \\
1,500 \\
1,400 \\
1,200\end{array}$ & $\begin{array}{l}\text { Moderate } \\
\text { Moderate } \\
\text { Moderate } \\
\text { Severe } \\
\text { Severe }\end{array}$ & $\begin{array}{r}\text { days } \\
- \\
296 \\
99 \\
107\end{array}$ & $\begin{array}{c}\text { gamma per liter } \\
- \\
64 \\
80 \\
59\end{array}$ & $\begin{array}{l}\text { days } \\
421 \\
421 \\
- \\
-\end{array}$ \\
\hline
\end{tabular}




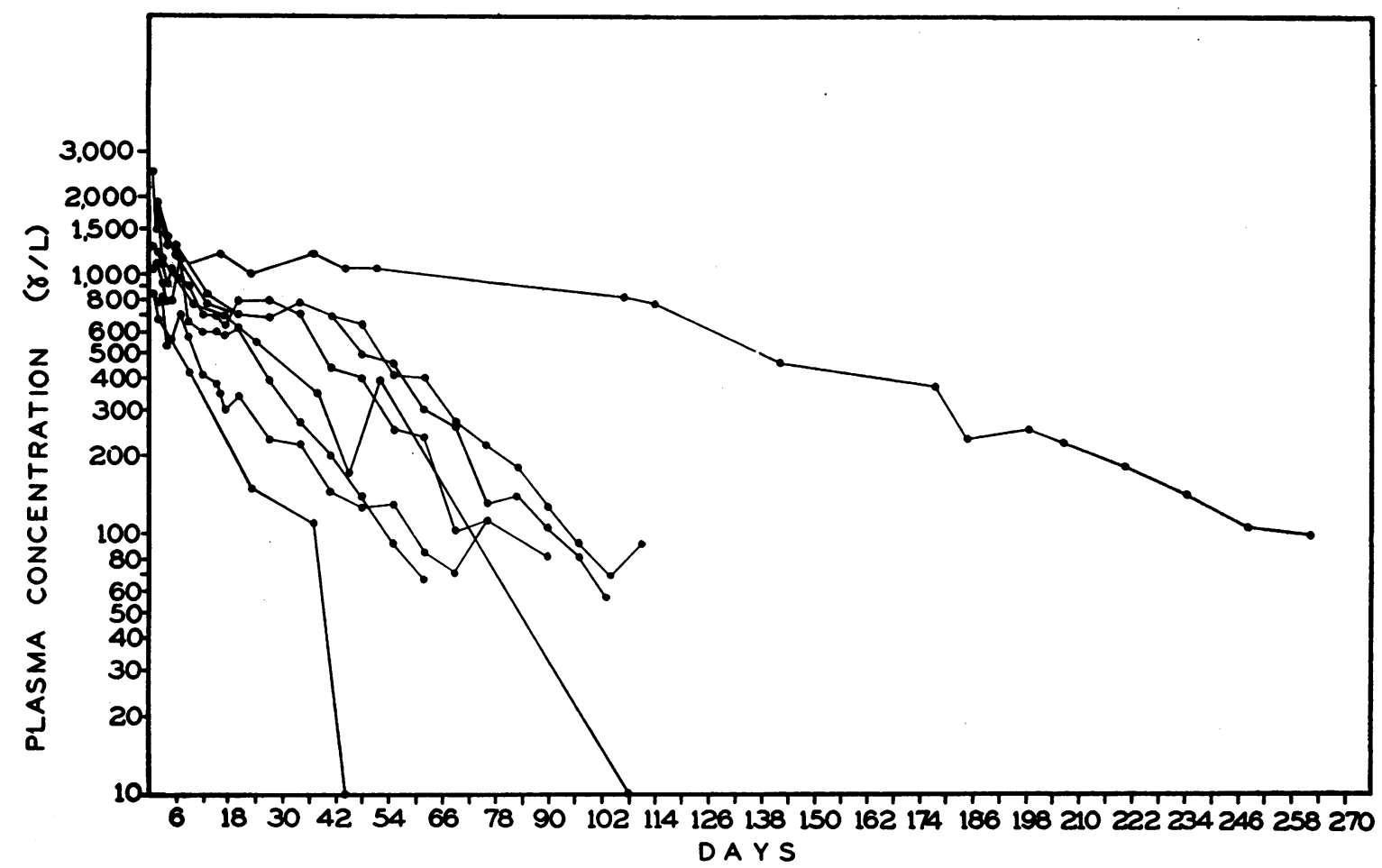

Fig. 2. Concentration of SN-10,275 in the Plasma of Eight Individuals after Oral Administration WAS Discontinued

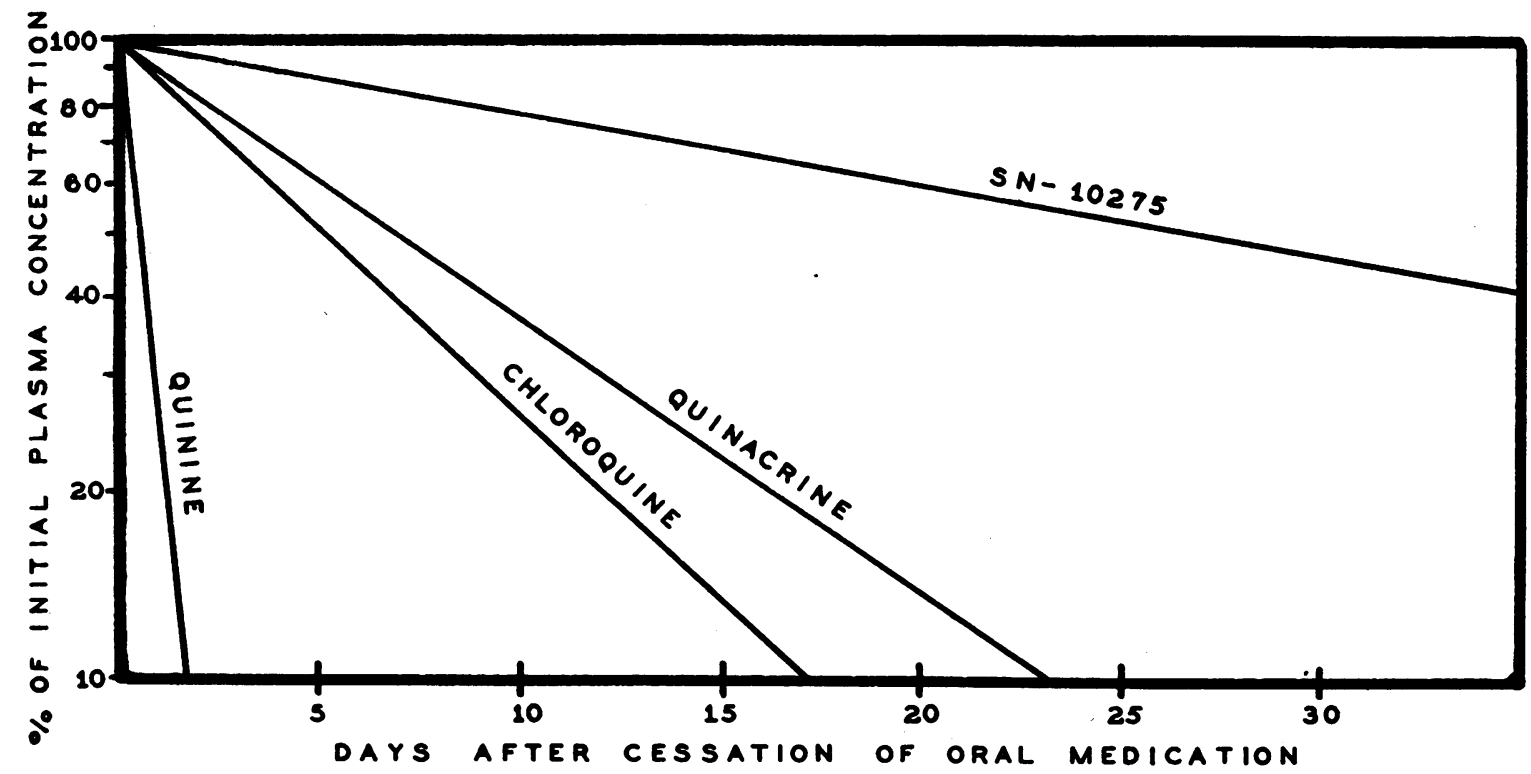

Fig. 3. Rate of Disappearance from the Plasma of Quinine, Chloroquine, Quinacrine (Atabrine), AND SN-10,275

Schematic representation in terms of per cent of initial plasma concentration. Curve for SN-10,275 plotted on basis of loss of 20 per cent per week as derived from curves presented in Figure 1. Curves for quinacrine and chloroquine plotted on basis of losses of 50 per cent per week (7) and 60 per cent per week (8), respectively. 
in his plasma more than twice the average time. The concentration of the drug in plasma decreased with time in approximately exponential fashion, the mean loss for the majority of the group being approximately 20 per cent per week. This is a much lower rate of disappearance than that shown by quinine and quinacrine (atabrine). Figure 3 illustrates schematically the comparative rates of decrease of plasma concentration of quinine, quinacrine, SN-10,275 and also that of the recently developed antimalarial, chloroquine $(6,8)$.

Toxicity. Eight patients received SN-10,275 at a dosage of 1.0 gram of the salt per day. One patient experienced mild gastrointestinal symptoms consisting of cramps, nausea and mild diarrhea during treatment. Another individual had fever of $102^{\circ} \mathrm{F}$., headache, and backache towards the end of the 14-day course of therapy. Physical examination and laboratory studies gave negative results or normal values. The fever persisted for about 12 hours. Three doses of the drug were omitted, but since the entire episode appeared innocuous, therapy was resumed with no untoward effects.

All eight patients manifested photosensitivity of the skin. This varied from a slight tingling of the facial skin to severe burning sensations in the same area accompanied by erythema. One individual had some desquamation of the skin of the nose, and another had mild labial edema. These symptoms appeared only after exposure to sunlight for periods of 15 minutes or more. With the exception of one individual who still had symptoms and detectable concentration of drug in the plasma ten months after he received $\mathrm{SN}-10,275$, this sensitivity to sunlight persisted for one-half to four months, gradually diminishing in intensity. Two subjects manifested increased irritability of the skin when subjected to mild mechanical trauma such as shaving or rubbing. Another patient noted smarting and burning of the eyes after exposure to sunlight. As shown in Table III, the severity and duration of these symptoms are roughly correlated with the mean concentration of SN-10,275 in the plasma during therapy. Abnormal amounts of porphyrins could not be detected in the urine of three patients.

\section{SUMMARY AND CONCLUSION}

In the prophylactic tests, $\mathrm{SN}-10,275$ did not prevent the development of malaria. Parasitemia appeared when the plasma concentrations had fallen to 66-110 gamma per liter. This required 66 to 97 days, a period six to nine times as long as the usual prepatent interval in controls.

In the therapeutic tests against attacks presenting a mild therapeutic challenge, one out of three patients underwent further relapse. This occurred when the plasma concentration had fallen to 64 gamma per liter, 296 days after termination of treatment with $\mathrm{SN}-10,275$. In the tests against the two attacks offering a severe therapeutic challenge, both patients suffered further relapse. Parasitemia appeared when the plasma drug levels fell to 59 and 80 gamma per liter, requiring 99 and 107 days, respectively.

The observed prolongation of the prepatent and latent periods may be attributed to the persistence

TABLE III

Clinical toxicity of $S N-10,275$ in eight volunteers

\begin{tabular}{|c|c|c|c|c|c|c|}
\hline Patient & $\begin{array}{c}\text { Mean } \\
\text { plasma } \\
\text { concentra- } \\
\text { tion }\end{array}$ & $\begin{array}{c}\text { Facial } \\
\text { tingling }\end{array}$ & $\begin{array}{c}\text { Facial } \\
\text { erythema }\end{array}$ & $\begin{array}{l}\text { Facial } \\
\text { edema }\end{array}$ & Duration & Comment \\
\hline & $\underset{\text { liter }}{\text { gamma per }}$ & & & & months & \\
\hline $\begin{array}{l}1 \\
2\end{array}$ & $\begin{array}{l}1,500 \\
1,400\end{array}$ & $\begin{array}{l}+t+ \\
++t\end{array}$ & $+\underset{0}{+}+$ & $\begin{array}{l}+ \\
0\end{array}$ & $\begin{array}{r}10 \\
4\end{array}$ & $\begin{array}{l}\text { Hyperirritability of skin on mechanical trauma. } \\
\text { Slight hyperirritability of skin on mechanical } \\
\text { trauma. Mild photophobia. }\end{array}$ \\
\hline 3 & 1,200 & +++ & +++ & 0 & 2 & Desquamation of nasal skin following sun burn \\
\hline 4 & 1,200 & ++ & + & 0 & $\frac{1}{2}$ & Headache, backache, and fever during drug \\
\hline $\begin{array}{l}5 \\
6 \\
7 \\
8\end{array}$ & $\begin{array}{l}860 \\
680 \\
550 \\
530\end{array}$ & $\begin{array}{l}+t \\
++ \\
+ \\
+t\end{array}$ & $\begin{array}{c}+ \\
\mathbf{0} \\
\mathbf{0} \\
+++\end{array}$ & $\begin{array}{l}\mathbf{0} \\
\mathbf{0} \\
\mathbf{0} \\
\mathbf{0}\end{array}$ & $\begin{array}{r}1 \frac{1}{2} \\
1 \frac{1}{2} \\
1 \frac{1}{2}\end{array}$ & Fair complexion. \\
\hline
\end{tabular}


in the body fluids of $\mathrm{SN}-10,275$ for long periods of time. Butler (9) has shown that the drug is almost entirely in undegraded form. ${ }^{5}$ The concentration of drug in the plasma at the time that parasitemia became patent was of the same order of magnitude in all patients studied. One individual showed a latent period after treatment three times that of the others. However, in this individual the rate of loss of drug was much lower, so that at the time of relapse, his plasma concentration was within the range observed in the other patients.

Similarly, the same individual showed persistence of photosensitivity far longer than the remainder of the group. The degree of tingling of the skin showed a positive correlation with the initial plasma concentration achieved, and the duration of this symptom was roughly proportional to the rate of loss of drug from the plasma.

The toxic manifestations and the variation in rate of disappearance from the body of $\mathrm{SN}-10,275$ limit the value of the drug as a suppressive agent. However, further investigation of constitutionally related compounds is indicated because a non-toxic drug which retained the antimalarial activity of $\mathrm{SN}-10,275$ and remained in the body for long periods of time, would have great value in the chronic suppression of malaria.

\section{BIBLIOGRAPHY}

1. Wiselogle, F. Y., editor, A Survey of Antimalarial Drugs, 1941-1945. Edwards Brothers, Inc., Ann Arbor, 1946.

2. Alving, A. S., Craige, B., Jr., Pullman, T. N., Whorton, C. M., Jones, R., Jr., and Eichelberger, L., Procedures used at Stateville Penitentiary for the testing of potential antimalarial agents. J. Clin. Invest., 1948, 27, Suppl., 2.

5 It is of interest to note that quinine (10 to 12) and other cinchona alkaloids $(13,14)$ are degraded in the body by oxidation on the 2-position of the quinoline ring to form carbostyrils. SN-10,275 has a phenyl group on the 2-position and this substitution may account for the apparent absence of degradation products in the plasma.
3. Ehrman, F. C., Ellis, J. M., and Young, M. D., Plasmodium vivax, Chesson strain. Science, 1945, 101, 377.

4. Craige, B., Jr., Alving, A. S., Jones, R., Jr., Whorton, C. M., Pullman, T. N., and Eichelberger, L., The Chesson strain of Plasmodium vivax malaria. II. Relation between prepatent period, latent period and relapse rate. J. Infect. Dis., 1947, 80, 228.

5. Wiselogle, F. Y., editor, A Survey of Antimalarial Drugs, 1941-1945, Vol. I, p. 345. Edwards Brothers, Inc., Ann Arbor, 1946.

6. Pullman, T. N., Craige, B., Jr., Alving, A. S., Whorton, C. M., Jones, R., Jr., and Eichelberger, L., Comparison of chloroquine, quinacrine (atabrine), and quinine in the treatment of acute attacks of sporozoite-induced vivax malaria (Chesson strain). J. Clin. Invest., 1948, 27, Suppl., 46.

7. Armored Medical Research Laboratory, Fort Knox, $\mathrm{Ky}$, and the Commission on Tropical Diseases, Army Epidemiological Board, Preventive Medicine Service, Office of the Surgeon-General, United States Army. Plasma quinacrine concentration as a function of dosage and environment. Arch. Int. Med., 1946, 78, 64.

8. Loeb, R. F., Clark, W. M., Coatney, G. R., Coggeshall, L. T., Dieuaide, F. R., Dochez, A. R., Hakansson, E. G., Marshall, E. K., Jr., Marvel, C. S., McCoy, O. R., Sapero, J. J., Sebrell, W. H., Shannon, J. A., and Carden, G. A., Activity of a new antimalarial agent, chloroquine ( $S N-7618)$. Statement approved by the Board of Coordination of Malarial Studies. J. A. M. A., 1946, 30, 1069.

9. Butler, A. M., Personal communication.

10. Kelsey, F. E., Geiling, E. M. K., Oldham, F. K., and Dearborn, E. H., Studies on antimalarial drugs. The preparation and properties of a metabolic derivative of quinine. J. Pharmacol. \& Exper. Therap., 1944, 80, 391.

11. Mead, J., and Koepfli, J. B., The structure of a new metabolic derivative of quinine. J. Biol. Chem., 1944, 154, 507.

12. Knox, W. E., The quinine-oxidizing enzyme and liver aldehyde oxidase. J. Biol. Chem., 1946, 163, 699.

13. Brodie, B. B., Baier, J. E., and Craig, L. C., Cinchona alkaloids: 4. Metabolic products in human urine. Fed. Proc., 1946, 5, 168.

14. Welch, W. J., Taggart, J. V., Berliner, R. W., Zubrod, C. G., Earle, D. P., and Shannon, J. A., Cinchona alkaloids: 6 . Suppressive antimalarial activity of cinchonine carbostyril. Fed. Proc., 1946, 5, 214. 